\title{
Korelasi Historisitas Ilmu Hisab Rukyat Dengan Perkembangan Peradaban Islam
}

\author{
Li'izza Diana Manzil \\ Universitas Islam Negeri Walisongo Semarang \\ Manzilli19@gmail.com
}

\begin{abstract}
Abstrak
Sedikit orang khususnya orang awam yang memahami bahwa ilmu hisab dan rukyat bisa disebut juga sebagai ilmu falak. Hal ini disebabkan dalam implementasi ilmu falak banyak dijumpai praktek hisab (perhitungan) dan rukyat (observasi). Jika menengok beberapa tahun silam, praktek hisab rukyat sudah pernah diimplementasikan oleh Rasulullah SAW bahkan sebelum Islam datang. Dalam sejarah mencatat perkembangan ilmu hisab rukyat mengalami perkembangan yang pesat di dunia Islam. Terbukti dari lahirnya sejumlah tokoh cendikiawan muslim yang mahir dalam bidang ilmu astronomi, astrologi, matematika dan ilmu eksak lainnya. Selain itu banyaknya tulisan serta instrumen yang diciptakan tidak bisa dipungkiri peradaban Islam terus mengalami masa keemasan. Dari sini jelas menunjukkan historisitas ilmu hisab rukyat memiliki korelasi yang penting terhadap peradaban Islam, diantaranya dalam perhitungan dan kajian bendabenda langit untuk praktek Ilmu Falak mengalami tingkat ketilitian yang semakin akurat. Sehingga pesatnya ilmu hisab rukyat dari era Rasulullah hingga era modern menunjukkan bahwa peradaban Islam juga mengalami perkembangan yang pesat seiring perjalanan sejarah.
\end{abstract}

Kata kunci: Historisitas, Ilmu Hisab Rukyat, Peradaban Islam

\begin{abstract}
Few people, especially the layman who understands that the science of reckoning and rukyat can also be called as the science of falak (islamic astronomy). This is caused in the implementation of islamic astronomy science found manythe practice of reckoning (calculation) and rukyat (observation). If you look a few years ago, the practice of hisab rukyat has been implemented by Rasulullah SAW even before Islam came. In history noted the development of the science of hisab rukyat experienced rapid development in the Islamic world. it proven from the birth of a number of intellectual Muslim who are proficient in the astronomy, astrology, mathematics and other exact science. In addition, the number of writings and instruments created can not be denied Islamic civilization continues to experience the golden age. From this, it clearly shows the historicity of the science of hisab has an
\end{abstract}

Al Istinbath : Jurnal Hukum Islam vol. 3, no. 2, 2018

IAIN Curup-Bengkulu | p-issn: 2548-3374; e-issn: 2548-3382

Available online at : http://journal.staincurup.ac.id/index.php/alistinbath 
important correlation to Islamic civilization, such as in the calculations and studies of sky object for the practice of Falak Science experience the level of carefulness more accurate. So rapid the science of hisab rukyat science from the era of the Prophet until the modern era shows that Islamic civilization also experienced rapid development along the course of history.

Keywords : Historicality, Hisab Rukyat Science, Islamic Civilization

\section{Pendahuluan}

Seputar persoalan hisab dan rukyat dapat disebut sebagai persoalan falak. Penamaan ini berkaitan dengan adanya objek dari persoalan tersebut adalah falak (madar al-nujum). Persoalan ini dapat disebut persoalan astronomi karena dalam ilmu Bumi dan Antariksa (Kosmografi), penentuan persoalan tersebut berkaitan dengan benda-benda langit, sebagian kecil saja dari bendabenda langit yang menjadi objek perhitungan. ${ }^{1}$

Hisab berasal dari akar kata ${ }^{-}-\tau$, yang secara etimologi hisab berasal dari bahasa Arab yang berupa fi'il madli hasaba (حسب) artinya perhitungan. Kata basaba (حسب) senada dengan kata dzann (ظن) artinya menduga, menyangka atau mengira, kata i'tadda (اعتد) artinya memandang atau menganggap dan kata absha (احصى) artinya menghitung². Dalam bahasa Inggris kata ini disebut Arithmatic yakni ilmu pengetahuan yang membahas tentang seluk beluk perhitungan. ${ }^{3}$

Dalam al-Qur'an kata hisab banyak digunakan untuk menjelaskan hari perhitungan (yaumul hisab). Kata hisab disebutkan dalam al-Quran sebanyak 37 kali yang semuanya berarti perhitungan dan tidak memiliki ambiguitas arti. $^{4}$

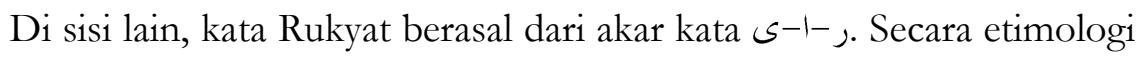
kata rukyat berasal dari bahasa Arab berupa fíil madli ro'a (راى ) yang diubah ke

${ }^{1}$ Ahmad Izzuddin, (Fiqih Hisab Rukyat, Jakarta: Penerbit Erlangga, 2007), hal.35.

${ }^{2}$ Ahmad Warson Munawwir, Al Munawwir Kamus Arab-Indonesia, (Surabaya: Penerbit Pusataka Progressif, 1997), hal.261.

${ }^{3}$ Direktorat Jenderal Pembinaan Masyarakat Islam, Almanak Hisab Rukyat, (Jakarta: Kementerian Agama RI, 2010), Cet-3, hal.20.

${ }^{4}$ Tono Saksono, Mengkompromikan Rukyat dan Hisab, Jakarta: Amythas Publicita, 2007), hal.120. 
bentuk masdar rujyatan (رؤية) artinya melihat. Dalam kamus al Munawir kata ro'a senada dengan kata abshara (ابصر) artinya melihat, kata adroka (ادرك) artinya mengerti dan kata hasiba (حسب) artinya menyangka, menduga, atau mengira. Adapun secara terminologi rukyat merupakan melihat bulan baru pada hari ke-29 dalam bulan Kamariah setelah terbenamnya Matahari sebagai tanda dimulainya awal bulan Kamariah.

Namun bagi umat Islam, terutama dari kalangan dunia pendidikan Islam khususnya Klasik, persoalan ini populer dengan istilah persoalan hisab atau persoalan falak. Kemudian yang menjadi subtansi persoalan hisab rukyat sebagaimana lazim disebutkan dalam mabadi al-'asyrah pada setiap kitab falak, adalah persoalan waktu-waktu ibadah seperti shalat, zakat, puasa, haji, dan penentuan arah kiblat serta gerhana.

Ditinjau dari sejarahnya, hisab dan rukyat sebenarnya sudah berkembang sebelum Islam datang. Hal ini terbukti masyarakat Arab pra Islam sudah mengenal sistem kalender yakni kalender lunisolar dengan perhitungan 29 atau 30 hari dalam setiap 12 bulan, sehingga jumlah hari dalam satu kalender adalah 354 hari. $^{6}$

Hisab dan rukyat mulai mengalami perkembangan ketika zaman Rasulullah dan sahabat, dimana saat mulai ditetapkannya penanggalan hijriah sebagai kalender Islam dan para sahabat Nabi yang sudah mulai melakukan perhitungan terhadap rotasi Bumi.

Hisab dan rukyat mengalami punjak kejayaannya pada masa daulah Bani Abbasiyah (abad ke-8 sampai ke-13). Saat itu peradaban Islam mengalami masa keemasan. Ilmu hisab dan rukyat berkembang saat luas hingga melahirkan tokoh-tokoh hebat diantaranya Ulugh Beik (1344-1449 M). Selain itu banyak tulisan-tulisan yang dibukukan membahas astronomi, ilmu nujum (astrologi), dan matematika yang saat ini masih digunakan oleh bangsa Barat sebagai rujukan.

Artikel ini akan memaparkan perkembangan ilmu hisab rukyat dari perspektif historis mulai pada masa Rasulullah, masa Sahabat, tabi'in, tabi'in, Abad pertengahan, hingga masa modern. Artikelini juga akan memaparkan secara singkat tokoh-tokoh yang berpengaruh dalam perkembangan ilmu hisab dan rukyat serta karya-karyanya. Selain itu, dalam artikel ini akan dipaparkan korelasi hisab dan rukyat terhadap pesatnya peradaban Islam yang mana di dalam literatur-literatur masih sedikit ada yang membahasnya .

\footnotetext{
${ }^{5}$ Ahmad Warson Munawwir, Al Munawwir Kamus Arab-Indonesia, hal.460.

${ }^{6}$ Muh. Nashirudin, Kalender Hijriah Universal, (Semarang: el-Wafa, 2013), hal.60.
} 


\section{Pembahasan}

\section{Historisitas Hisab dan Rukyat}

\section{Hisab dan Rukyat Masa Rasulullah, Sahabat dan Tabi'in}

Dalam hadis Nabi: inna umati umiyyatun la naktubu wala nabsibu menunjukkan bahwa pada masa awal Islam yakni masa Rasulullah, ilmu hisab belum masyhur di kalangan umat Islam. Meskipun sebagian di antara sudah ada yang mahir dalam hal perhitungan. Sehingga realitas persoalan hisab rukyat pada masa itu tentunya sudah ada walaupun dari sisi hisabnya tidak begitu masyhur. Sebenarnya perhitungan tahun Hijriah pernah digunakan sendiri oleh Nabi Muhammad ketika beliau menulis surat kepada kaum Nasrani Bani Najran, tertulis ke-5 Hijriah. ${ }^{8}$ Namun penamaan tahun di bangsa Arab selalu dikaitkan dengan peristiwa-peristiwa yang terjadi, seperti tahun Gajah karena pada tahun kelahiran Nabi terjadi penyerangan pasukan yang menaiki gajah ke Kakbah. Tahun Izin karena diizinkannya hijrah ke Madinah, tahun Amar yang berkenaan dengan diperintahkannya membela diri dengan menggunakan senjata dan tahun Zilzal adalah tahun terjadinya gonjnag-ganjing pada tahun ke-4 Hijriah.

Pada saat Islam sudah berkembang di Jazirah Arab, praktek rukyat sudah dilakukan untuk menentukan awal bulan kamariah pada akhir bulan, atau menggenapkan umur bulan menjadi tiga puluh hari (istikmal). Hal ini sesuai dengan kebiasaan masyarakat Arab pra Islam dan sabda Rasulullah mengenai penentuan awal bulan Ramadan dan Syawal, ${ }^{10}$ yaitu:

$$
\begin{aligned}
& \text { حدثنا إسماعيل عن ايوب, عن نافع عن ابن عمر رضي الله عنهما قال: قال رسول اللّ } \\
& \text { صلى الله عليه و سلم انما الشهر تسع وعشرون فلا تصوموا حتي تروه و لا تفطروا حتي } \\
& \text { تروه فإن غم عليكم فاقدرو اله (رو اه مسلم) }
\end{aligned}
$$

${ }^{7}$ Al-Bukhari, Shabih Bukhari, (Mesir: Musthafa al-Babi al-Halabi, tth), juz III, hal.34.

${ }^{8}$ Izzuddin, Fiqib Hisab Rukyat, hal.50. 1994), hal.2.

9 Sofyan Jannah, Kalender Hijriah dan Masehi 150 Tahun, (Yogyakarta: UII Press,

${ }^{10}$ Taufiq, Perkembangan Ilmu Hisab di Indonesia, dalam Selayang Pandang Hisab Rukyat, (Jakarta: ttp, 2004), hal.17. 
Telah mengabarkan kepada kami Ismail, telah menceritakan kepada kami Ayyub dari Nafi' dari Ibnu Umar ra. Berkata Rasulullah saw bersabda: satu bulan adalah dua pulub sembilan hari, maka janganlab kalian berpuasa sampai kalian melihatnya (bilal), dan janganlah kalian berbuka sampai kalian melihatnya, jika tertutup awan maka perkirakanlab"."

Pada masa Khulafaurrasyidin, hisab dan rukyat sudah tampak dari adanya penetapan hijrah Nabi dari Makkah ke Madinah sebagai dasar permulaan kalender Hijriah yang dilakukan oleh sahabat umar bin Khattab tepatnya tahun ke-17 Hijriah, dan menetapkan bulan Muharam sebagai awal bulan Hijriah diantara 12 bulan lainnya. ${ }^{12}$

Sebenarnya pada zaman pra-Islam sudah berkembang ilmu hisab. Ini hal ini terlihat dari bukti penemuan arkeologis tempat ilmu hisab diajarkan. Bahkan menurut Masyhuri di kalangan sahabat ada yang ahli hisab. Dia menunjukkan bahwa ibn Abbas merupakan salah seorang ahli hisab, karena dia telah menghitung rotasi bulan dalam setahun sebanyak dua puluh kali (man 2 ilab). ${ }^{13}$

Dengan demikian, perkembangan hisab dan rukyat pada masa Rasulullah dan sahabat masih dalam tahap yang masih primitif dan sederhana. Karena pada masa Rasulullah beliau yang menjadi peletak dasar hisab dan rukyat meskipun pada saat itu hisab belum begitu masyhur. Pada masa sahabat hisab dan rukyat mulai tampak dengan mulai diberlakukannya kalender Hijriah oleh khalifah Umar bin Khattab yang dihitung berdasarkan peristiwa hijrah Rasulullah dari Makkah ke Madinah.

\section{Hisab Rukyat pada Masa Tabi'in sampai Periode Klasik}

Dalam sejarah, setelah mengalami vacum selama hampir delapan abad tidak tampak adanya masa keemasan dalam dunia hisab rukyat. Baru di masa Daulah Abasiyyah (abad ke-8 sampai ke-13) mulai tampak masa kejayaan. Sebagaimana di masa Khalifah Abu Ja'far al-Manshur, hisab rukyat dalam ilmu astronomi mendapat perhatian khusus, seperti upaya menerjemahkan kitab Sbindhind dari India. ${ }^{14}$

Setelah Islam meluas dari Andalusia hingga Indus, hisab dan rukyat semakin berkembangmelalui ilmu Hisab (astronomi), ilmu nujum (astrologi) dan matematika di samping ilmu eksakta lainnya. Ilmu-ilmu tersebut

\footnotetext{
${ }^{11} \mathrm{Abu}$ Husain Muslim bin al Hajjaj, Shahih Muslim, Jilid 2, (Beirut: Dar al-Fikr, tt), hal.759.

${ }^{12}$ Izzuddin, Fiqih Hisab Rukyat, hal.50.

${ }^{13}$ Susiknan Azhari, Kalender Islam ke Arab Integrasi Mubammadiyah-NU, (Yogyakarta: Museum Astronomi Islam, 2012), hal.54.

${ }^{14}$ Izzuddin, Fiqih Hisab Rukyat, hal.50.
} 
dicangkok dari Yunani, Mesir dan India, yang kemudian dikembangkan dengan melakukan percobaan, hitung-menghitung, dan observasi. ${ }^{15}$

Kemudian pada masa Khalifah al-Makmun, naskah Tabril Maghesti diterjemahkan dalam bahasa Arab. Dan dari sini lahir istilah ilmu hisab sebagai salah satu dari cabang ilmu keislaman dan tumbuhnya ilmu hisab tentang penentuan awal waktu shalat, penentuan gerhana, awal bulan kamariah, dan penentuan arah kiblat yang dikenal dengan sebutan ilmu falak. ${ }^{16}$ Tokoh yang hidup di masa ini adalah sultan Ulugh Beik, Abu Raihan, Ibnu Syatir, dan Abu Manshur al-Balkhiy. Observatorium didirikan alMakmun di Sinyar dan Junde Shahfur Bagdad, dengan meninggalkan teori Yunani kuno dan membuat teori sendiri dalam menghitung kulminasi Matahari. Dan juga menghasilkan data-data yag berpedoman pada buku Shindhindy yang disebut Tables of Makmun dan oleh orang Eropa dikenal dengan Astronomos atau Astronomy. ${ }^{17}$

Khalifah al-Makmum merupakan khalifah ke-7 Bani Abbasiyah mendirikan institusi yang bernama Baitul Hikmah di kota Baghdad. Institusi ini adalah institusi keilmuan astronomi yang dilengkapi dengan perpustakaan dan observatorium. Pendirian observatorium ini memberikan dampak penting bagi kemajuan astronomi saat itu khususnya yang berkaitan hisab rukyat. al-makmun juga mendirikan observatorium lainnya di kota Tadmor. ${ }^{18}$

Khalifah Sharaf dari Bani Buwayhid juga mendirikan beberapa observatorium pada tahun $954 \mathrm{M}$ bagi para astronom yang bekerja padanya.

Masa kejayaan itu juga ditandai dengan adanya al-Farghani seorang ahli falak, yang oleh orang Barat dipanggil Farganus, buku-bukunya diterjemahkan oleh orang Latin dengan nama Compendium yang dipakai pegangan dalam mempelajari ilmu perbintangan oleh astronom-astronom barat seperti Regiomontanus. ${ }^{19}$

Kamudian Maslamah bin al-Marjiti di Andalusia telah mengubah tahun Persi menjadi tahun Hijriah dengan meletakkan bintang-bintang sesuai dengan awal tahun Hijriah. di samping itu, ada juga pakar falak kenamaan lainnya seperti Mirza ulugh bin Timurlank yang terkenal dengan ephemerisnya, Ibnu Yunis (950-100 M), Nasiruddin (1201-1274 M) dan

\footnotetext{
15 Taufiq, Perkembangan Imu Hisab di Indonesia, hal.17.

${ }^{16}$ Izzuddin, Fiqib Hisab Rukyat, hal.51.

${ }^{17}$ Izzuddin, Fiqib Hisab Rukyat, hal.51.

18 Anton Ramdan, Islam dan Astronomi, (Jakarta: Bee Media Indonesia, 2009), hal.59.

${ }^{19}$ Izzuddin, Fiqib Hisab Rukyat, hal.51.
} 
Ulugh Beik (1344-1449 M) yang terkenal dengan landasan ijtimak dalam penentuan awal bulan kamariah. ${ }^{20}$

Di Bashrah ada Abu Ali al-hasan bin al-haytam (965-1039 M) seorang pakar falak yang terkenal dengan bukunya Kitab al-Manazhir dan tahun 1572 diterjemahkan dengan nama Optics yang merupakan temuan baru tentang refraksi (sinar bias). Tokoh-tokoh tersebut sangat mempengaruhi dan memberikan kontribusi yang positif bagi perkembangan ilmu Falak di dunia Islam pada masanya masing-masing. Meskipun masih terkesan bernuansa Ptolomeus. $^{21}$

Pada abad ke-9 mulai muncul cendikiawan-cendikiawan muslim yang mempelajari astronomi. Mereka mempelajari ilmu-ilmu astronomi yang berasal dari India, Yunani, Babilonia, dan lain sebagainya. ${ }^{22}$

Pada masa ini ilmu hisab juga dikenal dengan munculnya karya-karya monumental seperti Kitab al-Mukhtashar fi Hisab al-Jabr wa al-Muqabalah ditulis oleh Abu Ja'far Muhammad Ibn Musa al-Khawarizmi sekitar tahun 210 H/825 M di Baghdad, Kitab al-Fusul fi Hisab al-Hindi disusun pada tahun 390 H/1000 M oleh Abu al-Hasan Kusyar bin Labban al-Djili, Takmila fi ím alHisab ditulis oleh Abu Mansur 'Abd al-Kahir al-Baghdadi (w. 428 H/1037 M), Sumtu al-Qiblah fi al-Hisab karya Ibn Haitham (w. 430 H/1039 M), dan alQanun al-Mas'udiy fi al-Haiah wa an-Nujum karya Abul Rayhan Muhammad bin Ahmad al-Biruni (362 H-490 H/973-1049 M). ${ }^{23}$

Pada masa kejayaan bani abbasiyah ini, kekuasaan Islam di Spanyol juga keilmuan berkembang pesat. Walaupun secara politik kedua wilayah tersebut saling bermusuhan, namun para cendikiawan saling bertukar pikiran pengetahuan. Dalam bidang astronomi, Ibrahim ibn Yahya merupakan orang yang dapat menghitung terjadinya gerhana Matahari dan menentukan berapa lama waktunnya. Ia juga membuat teropong modern yang dapat digunakan untuk menentukan jarak antara tata surya dan bintang-bintang. Abbas ibn Farmas seorang cendikiawan yang ahli dibidang kimia dan astronomi berhasil membuat kaca dari batu. Pada abad ke-13 kekuasaan Islam di Spanyol mulai berakhir. $^{24}$

\footnotetext{
${ }^{20}$ Izzuddin, Fiqib Hisab Rukyat, hal.51.

${ }^{21}$ Izzuddin, Fiqib Hisab Rukyat, hal.52.

22 David A King, Astronomi in The Servic of Islam, (Great Britain: Voriorium Ashgate Publishing, 1993), hal.251.

${ }^{23}$ Susiknan Azhari, Kalender Islam ke Arah Integrasi Mubammadiyah-NU, hal.54. 1961), hal.168.

24 A. Pannekoek, A. History of Astronomy, (New York: Dover Publications Inc,
} 
Adapun ilmuwan-ilmuwan Muslim ahli hisab rukyat bidang astronomi yang berkembang pada masa ini beserta karya ilmiahnya ${ }^{25}$ adalah:

a. Muhammad al-Fazari (700-825M) karyanya adalah kitab Zij alShindhind.

b. Al-Khawarizmi (780-850M) karyanya adalah al-Kitab al-Mukbtasar fi Hisab al-Jabr wal-Muqabala (The Compendious Book on Calculation by Completion and Balancing).

c. Yaqub Ibn Ishaq Ibn Sabah al-Kindi Abu Yusuf (Alkindus) (800873M) karyanya adalah Risalah fi 'ilal al-Awda' Noujoumia (Positions of the Stars) dan Risalah fi Sina'at al-Usturlab (Making of the Astrolabe).

d. Sanad Ibn Ali (850M) karyanya adalah Kitab Hisab al-Hindi, Kitab al-Jama' wa Tafriq, Kitab al-Jabr wa al Mufaraqa dan Kitab al-Munfasilat wa al Mutawassitat.

e. Al-Farghani (850M) karyanya adalah Kitab Fi Jawani (A Compendium of The Science of Stars).

f. Ali Ibnu Younis (825-1025M) karyanya adalah Pendulum (bandul) dan Sundial.

g. Abu Abdallah Mohammad ibn Jabir ibn Sinan al-Raqqi al-Harrani al-Sabi al-Battani (al-Battani) karyanya adalah Kitab al-Zij. ${ }^{26}$

h. Banu Musa Ibn Shakir (872M) karyanya adalah Kitab al-Hiyal, Kitab Missahat al Akr, Kitab Kismat Arzawaya ila Talatat Akssam Mutassawiya, Kitab Chalk al Handassi, Kitab Harakat al Falak al Ula. ${ }^{27}$

i. Ma Yize ${ }^{28}(885 \mathrm{M})$ karyanya adalah Kalender China Ying Tian Li.

j. Abd al-Rahman al-Sufi (903-986M) karyanya adalah Book of Fixes Star, Kitab al-Kawakib al-Thabita (Book of the Stationary Planets), Risalat al-Amal bil Usturlab (Treatixe on the Use of Astrolabe), Kitab Tadrika, Kitab Matarih Chua'at, Kitab al-Urjura fi al-Kawakib Tabita, Peta (Globe) Langit, menyebut Galaksi Andromeda sebagai "small cloud" (kabut kecil).

k. Abu al-Wafa Muhammad Ibnu Muhammad ibnu Yahya ibnu Ismail ibnu al-Abbas al-Bazjani (940-998M) karyanya adalah Kitab

${ }^{25}$ Anton Ramdan, Islam dan Astronomi, hal.175-181.

${ }^{26}$ Dalam kitab ini al-Battani melakukan hisab dengan membagi kalender Matahari menjadi 365 hari, 5 jam, 46 menit dan 24 detik.

${ }^{27}$ Ibn Shahir juga membuat Kalender Matahari Persia dan Membuat Katalog tata letak planet-planet.

${ }^{28}$ Beliau merupakan kepala Badan Penelitian Astronomi Dinasti Song. 
fina Yabtaju Ilaibi al-Kuttab wa al-Ummal min Ilm al-Hisab Book on What Is Necessary from the Science of Arithmetic for Scribes and Businessmen), Kitab al-Kamil (The Complete Book), Kitab al-Majesti Almagest Book), Hukum identitas trigonometri dan hukum dan hukum sinus untuk geometri bola, Abul Wafa crater.

1. Abu Said Ahmad ibn Muhammad ibn Abd al-Jalil al-Sijzi (945M) karyanya adalah Planetarium al-Sijzi, Book of the measurement of spheres by spher.

m. Abu al-Qasim Maslama Ibn Ahmed Ibn Qasim Ibn Abdullah alMajriti (Almajriti) (950-1007M) karyanya adalah Rissala fi alUsturlab (Astrolabe Treatise), Sharb Kitab al-Majesti li Batlimus (Commentary of Ptolemy's Almagest), Kitab Timar al-Adad fi al-Hissab.

n. Abu Rayhan Muhammad Ibnu Ahmad Biruni (Al Biruni) (9731048M) karyanya adalah Kitab al-Qanun al-Mas'udi, al-Tafbim li Awail Sina'at al-Tanjim (Element of Astrology). ${ }^{29}$

o. Ibnu al-Haytam (Alhazen) (965-1040M) karyanya adalah al-Shuku ala Batlamyus (Doubts On Ptolemy), Maqalah fi Hay'at Alam (Treatise on the Configuration of the World). ${ }^{30}$

p. Al-Zarqali (Arzachel) (1028-1087M) karyanya adalah Kitab al Amal bi Assahifa az-Zijia, Kitab Attabdir, Kitab al Madkhal fi Ilm Annoujoum, Rissalat fi Tarikat Istikhdam as-Safiha al-Moushtarakah li Jamia alOuroud. ${ }^{31}$

q. Al-Khazini (1121M), karyanya adalah The Book of the Balance of Wisdom. ${ }^{32}$

r. Ibnu al-Shatir (1300-1375 M) karyanya adalah Kitab Nihayat al-Usul fi Tashih al-usul (The Final Quest Concerning The Rectification of Principles),Zij al-Jadid (The New Astronomical Table), Rissala fi alOstorlab (Treatise on Astrolabe), Mukhtashar al Amal bi al Usturlab

${ }^{29}$ Beliau menghitung jari-jari Bumi sebesar 6339,5 km

${ }^{30}$ Beliau meneliti Bintang dan radiasi cahayanya

31 Beliau menemukan bahwa orbit (garis edar) Matahari dan Planet mengelilingi Bumi berbentik Elipse bukan lingkaran, membuat astrolabe, membuat tabel toledo dan mempublikasikan Toledo tables memaparkan instrumen-instrumen astronomi dan kegunaan astrolabe. Ia melakukan beberapa pengamatan yang menyimpulkan apogee Matahari sebesar $77^{\circ} 50^{\prime}$ yang lebih akurat dari pendapat al-Battany, lihat A. Pannekoek, A Histrory of Astronomy, (New York: Dover Publications Inc, 1961), hal.168.

32 Al-Khazini menyatakan bahwa gaya gravitasi bergantung pada jarak benda tersebut dari pusat Bumi. 
Li’izza Diana Manzil: Korelasi Historisitas Ilmu Hisab Rukyat Dengan Perkembangan | 194

(Summary of Astrolabe), jam Matahari Ibnu al-Shatir, Kotak Kronometri.

Diantara karya-karya, instrumen dan situs hisab rukyat pada masa ini, adalah

a. Zij Khaqani

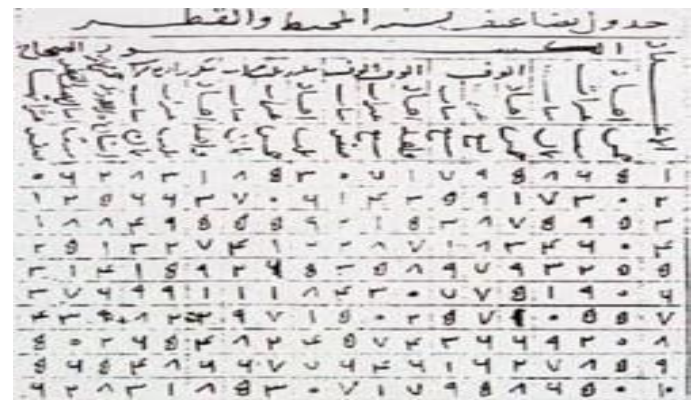

Gambar 1. Risalah Instrumen Obervasi Astronomi ${ }^{33}$

Sebuah buku tabel astronomi karya Khaqani Zij, jika diterjemahkan dalam bahasa Indonesia berjudul Risalah Instrumen Observasi Astronomi. Buku ini menjelaskan berbagai macam instrumen yang berbeda dalam observasi astronomi, seperti triquetrum, bola armillary, equinoctial armillary dan solsticial armillary, sinus, sextant dan lain sebagainya.

b. Penterjemahan Buku

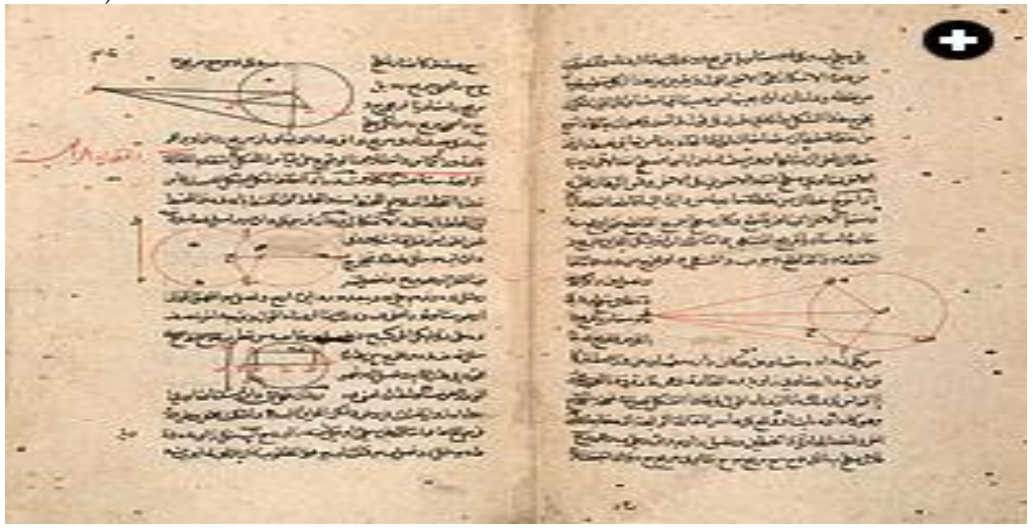

Gambar 2. Elements of Geometry ${ }^{34}$

${ }^{33}$ https:/ / tikotea.wordpress.com/2009/09/16/sumbangan-saintis-muslim-dalamgeometri/ diakses pada tanggal 22 September 2017 pukul 21:08 WIB.

${ }^{34} \mathrm{http}: / /$ archive.aramcoworld.com/issue/200703/rediscovering.arabic.science.htm diakses pada tanggal 22 September 2017 pukul 21:08 WIB. 
Salah satu contoh penterjemahan ke dalam bahasa Arab buku Elements of Geometry yang pernah dilakukan oleh ulama sekaligus ilmuwan Persia yakni Nasir al-Din al-Tusi. Karya tersebut meruapakan salah satu risalah Yunani paling awal tentang matematika.

c. Spherical Astrolab

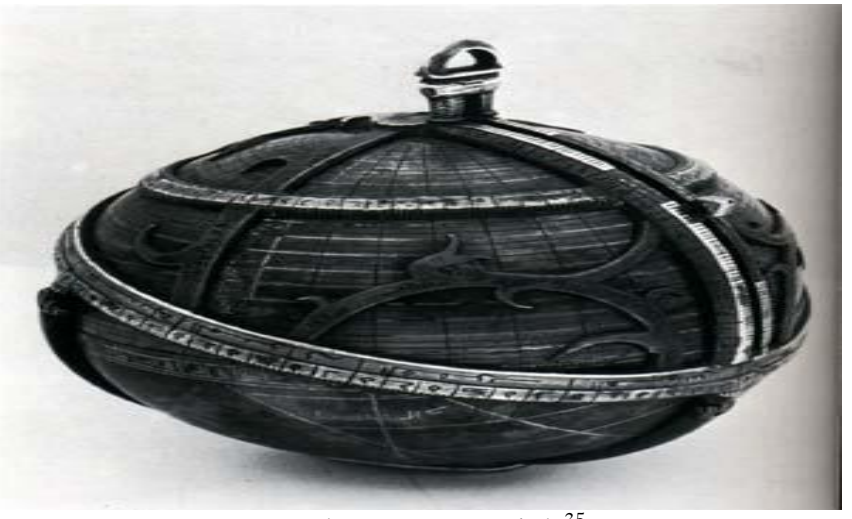

Gambar 3. Astrolab ${ }^{35}$

Dibuat sekitar tahun 1480 M. Merupakan sebuah peta bintang yang berbentuk globe dengan petunjuk 19 bintang tetap. Dimana lingkarang ekliptika besarnya memakai nama tanda zodiak.

d. Diagram orbit Merkurius
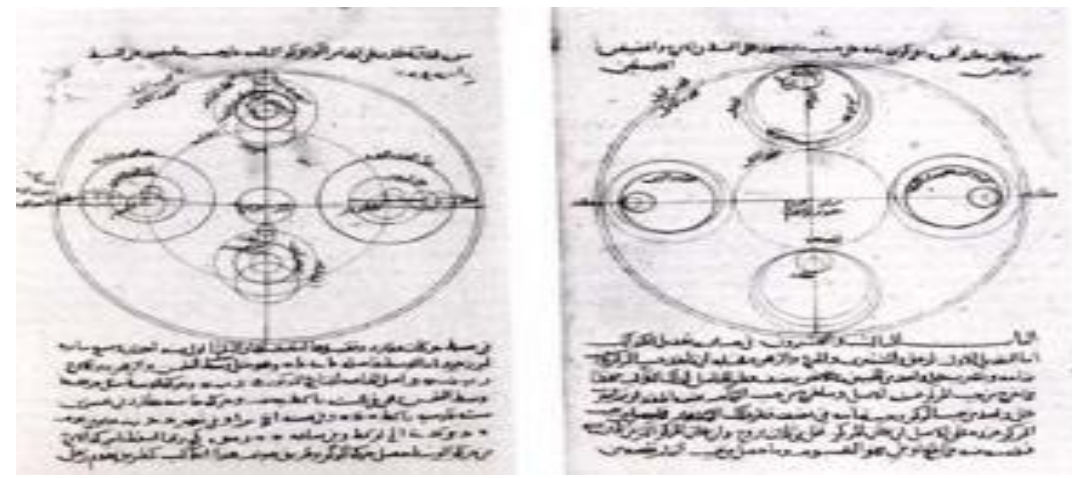

\section{Gambar 4. Kitab Nihayat al-Sulir ${ }^{36}$}

Dibuat sekitar abad ke-14. Ini merupakan karya Ibn ash-Shatir dalam kitab Nihayat al-Sulir. Dua diagram diatas pada ilustrasi pertama

\footnotetext{
${ }^{35} \mathrm{http}: / /$ www.themodernreligion.com/basic/history/photographs_science.htm diakses pada tanggal 23 September 2017 pukul 07:28 WIB.

${ }^{36} \mathrm{http}: / /$ www.themodernreligion.com/basic/history/photographs_science.htm diakses pada tanggal 24 September 2017 pukul 09.15 WIB.
} 
yang berhasil merepresentasikan gerakan planet merkurius yang scara eksklusif dalam hal rotasi melingkar yang seragam.

e. Astrolab

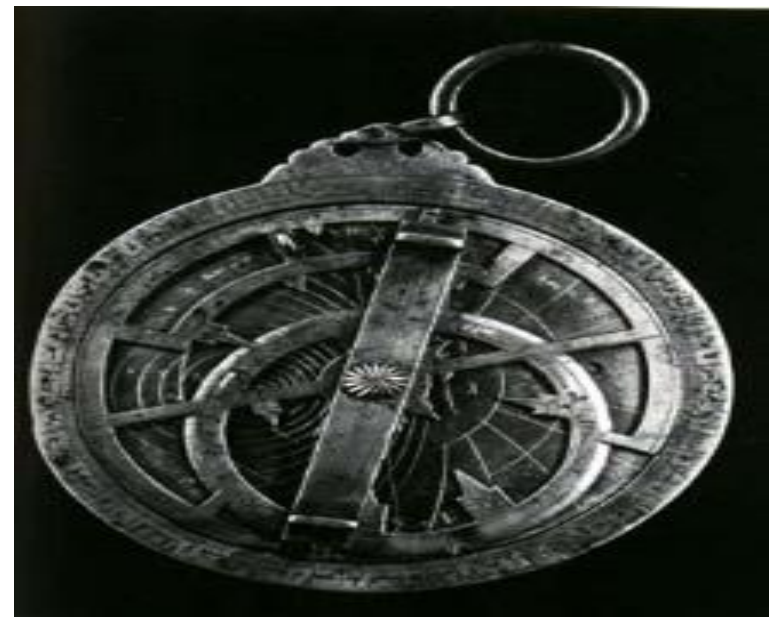

Gambar 5. Astrolab ${ }^{37}$

Dibuat sekitar abad ke-9. Alat ini digunakan untuk mengukur ketinggian benda langit di atas horizon dan juga untuk menentukan waktu siang dan malam.

\section{f. Celestial Sphere}

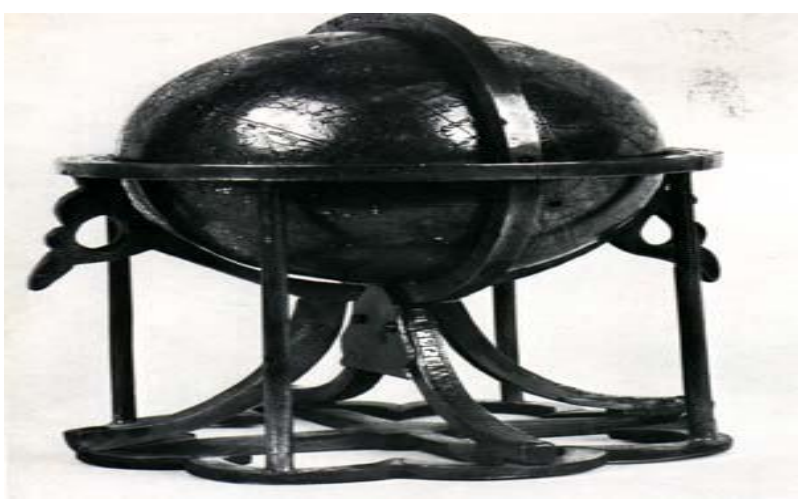

Gambar 6. Celestial Sphere ${ }^{38}$

${ }^{37}$ http://www.themodernreligion.com/basic/history/photographs_science.htm diakses pada tanggal 23 September 2017 pukul 07:28 WIB.

${ }^{38} \mathrm{http}: / /$ www.themodernreligion.com/basic/history/photographs_science.htm diakses pada tanggal 24 September 2017 pukul 10.09 WIB. 
Celestial Sphere dibuat sekitar tahun 1285. Instrumen ini berasal dari Iran yang mana memberikan informasi yang berasal dari Book of Fixed Stars karya Abd ar-Rahman as-Sufi.

g. Observatorium

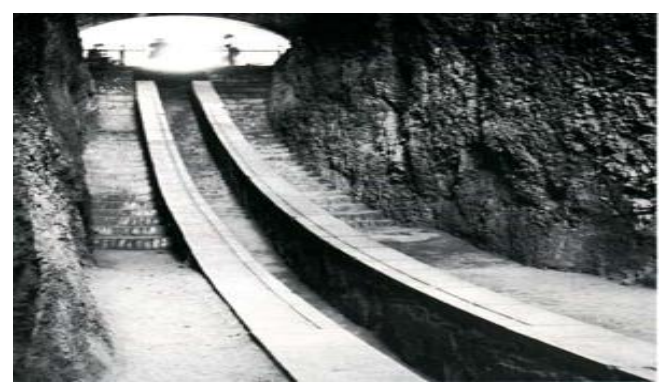

Gambar 7. Observatorium di Samarkand ${ }^{39}$

Observatorium yang dibangun di Samarkand ini merupakan observatorium yang paling besar saat itu. Palungan ini mendukung untuk sebuah busur besar yang dipasang di pesawat meridian. Bendabenda langit yang melintasi pesawat ini akan mejatuhkan cahayanya yang pertama melalui lubang di pusat busur ke sebuah alas silinder, dari situ ketinggiannya bisa dibaca.

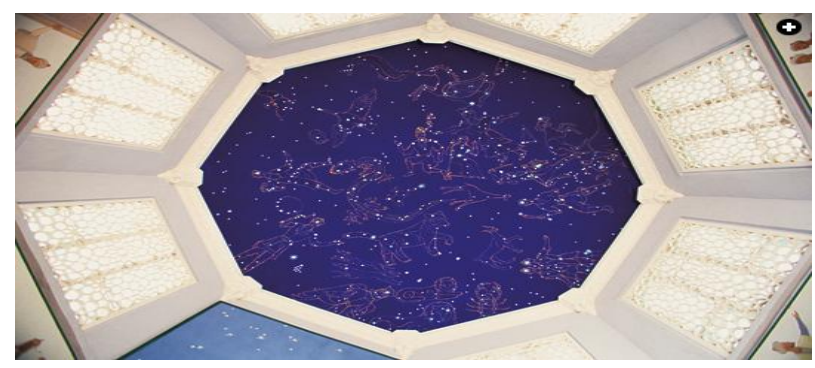

Gambar 8. Observatorium Ulugh Beik ${ }^{40}$

Ini merupakan sebuah lukisan rasi bintang yang menghiasi langit-langit observatorium Ulugh Beik yang terkenal di Samarkand, Uzbekistan, yang mengambil namanya dari pendirinya, cucu Tamerlane, dan diresmikan sekitar pada tahun 1420 .

Dengan demikian, Hisab Rukyat pada masa tabi'in hingga periode Klasik mulai berkembang pesat dan mencapai zaman keemasan khususnya pada masa bani abbasiyah yang ditandai dengan munculnya ilmuwan-ilmuwan Islam dengan membuat teori-teori dan

\footnotetext{
${ }^{39} \mathrm{Ibid}$

${ }^{40} \mathrm{http}: / /$ archive.aramcoworld.com/issue/200703/rediscovering.arabic.science.htm
} 
alat-alat astronomi baru, penerjemahan buku-buku ke dalam bahasa Arab, serta penulisan buku-buku karangan mereka yang mana diterjemahkan oleh ilmuwan Barat dan dijadikan rujuka hingga saat ini.

\section{Hisab dan Rukyat pada Masa Pertengahan (abad ke-14 sampai abad ke-18).}

Perkembangan hisab rukyat pada masa ini terlihat jelas dalam bidang ilmu astronomi. Ilmu astronomi pada masa kejayaan Islam berpengaruh hingga keluar wilayah Islam. Wilayah yang paling terpengaruh dengan astronomi Islam adalah wilayah Eropa. Pengaruh asttronomi Islam ke Eropa masuk melalui Andalusia (Spanyol). ${ }^{41}$

Pada pertengahan abad $13 \mathrm{M}$ setelah Islam mengalami keemasan dalam bidang ilmu pengetahuan, terjadi ekspansi intelektual ke Eropa melalui Spanyol. Sedangkan Eropa pada waktu itu tengah dilanda tumbuhnya ismeisme baru seperti humanisme, rasionalisme, dan renaisans, sebagai reaksi dari filsafat Skolastik di masa itu, di mana orang dilarang menggunakan rasio atau paham yang kontradiksi dengan paham Gereja. ${ }^{42}$

Pada saat itu Spanyol termasuk ke dalam wilayah Islam. Selain melalui Andalusia, pengaruh Astronomi Islam juga masuk ke Eropa melalui Sisilia, wilayah yang dikuasai Islam hingga $1091 \mathrm{M}$ dan memiliki perkembangan ilmu pengetahuan yang tidak kalah dengan Andalusia. Para ilmuwan Eropa mulai tertarik dengan Astronomi Islam, sehingga mereka menerjemahkan banyak karya-karya Astronomi Islam. Salah satu buku astronomi Islam yang diterjemahkan yaitu the Elements of Astronomy yang diterjemahkna ke dalam bahasa Latin pada abad ke-12. Buku ini dikarang oleh al-Farghani. Buku ini juga diterjemahkan ke dalam bahasa Yahudi oleh ilmuwan Yahudi bernama Jacob Anatoli. ${ }^{43}$

Pada masa pertengahan, bangsa-bangsa Eropa mulai tertarik dengan ilmu pengetahuan yang dipelajari orang-orang Islam. Serangan dari bangsa Eropa mulai dilancarkan kepada negara-negara Islam. Akibatnya tidak sedikit perpustakaan yang penuh dengan buku-buku ilmu pengetahuan berserakan dan terbakar. ${ }^{44}$

Kebudayaan bangsa Eropa mulai berkembang dengan pesat. Mereka mempelajari semua pengetahuan peninggalan bangsa Arab yang telah runtuh

${ }^{41}$ Ramdan, Islam dan Astronomi, hal.70.

${ }^{42}$ Izzuddin,Fiqib Hisab Rukyat, hal.52.

${ }^{43}$ Ramdan, Islam dan Astronomi, hal.71.

${ }^{44}$ Khazin, Ilmu Falak dalam Teori dan Praktik, (Yogyakarta: Buana Pustaka, 2008), hal.25. 
kejayaannya. Merekameniru cara-cara hidup bangsa Arab dengan mendirikan sekolah-sekolah dan perguruan tinggi serta perpustakaan-perpustakaan. ${ }^{45}$

Ilmu hisab yang berkembang pada masa pertengahan ini didasarkan atas teori ptolomy atau teori geosentris ${ }^{46}$ atau homosentris. Sumber utama hisab rukyat ilmu astronomi pada masa itu adalah buku Almagest (ditulis di Mesir). ${ }^{47}$

Kemudian muncul Nicolas Copernicus (1473-1543 M) yang berupaya membongkar teori Geosentrisnya Claudius Ptolomeus dengan teori Heliosentris. Debat teori tersebut berkembang sampai abad 18, di mana penyelidikan Galilleo galilie dan John Keppler menyatakan pembenaran teori Heliosentris. Kemudian pada tahun-tahun berikutnya banyak ditemukan temuan-temuan seputar kosmografi. ${ }^{48}$

Namun dalam wacana historitas hisab rukyat Islam, tokoh yang pertama kali melakukan kritik tajam terhadap teori Geosentris adalah alBiruni, menurutnya tidak masuk akal karena langit yang begitu besar dan luas dengan bintang-bintangnya dinyatakan mengelilingi Bumi sebagai pusat tata surya. ${ }^{49}$

Pada masa ini dilakukan penterjemahan buku-buku ilmu falak ke dalam bahasa Eropa. Misalnya buku al-Mukhtashar fi Hisabil Jabr wal Muqabalah karya al-Khawarizmi diterjemahkan ke dalam bahasa latin oleh Gerard dari Cremona. Buku hasil terjemahan ini dengan judul barunya The Mathematics of Integration and Equations dipakai sebagai buku pegangan utama dalam ilmu pasti diperguruan-perguruan tinggi Eropa hingga abad $16 \mathrm{M}^{50}$

Buku Tabril al-Maghesti karya al-Battani diterjemahkan ke dalam bahasa Latin oleh Plato dari Tripoli (w. 1150 M), dan dikutip oleh Nicolas Copernicus dalam karangannya De Revolutionibus Orbium Coelestium. Buku Tabril al-Maghesti ini diterjemahkan ke dalam bahasa Inggris oleh Alphonso X, selain itu tabel bintang-bintang karya az-Zarqali diterjemahkan oleh Ramons dari Marsceilles. ${ }^{51}$

${ }^{45}$ Khazin, Ilmu Falak dalam Teori dan Praktik, hal.26.

46 Teori Geosentris adalah teori yang menyatakan bahwa Bumi merupakan pusat tata surya. Berasal dari kata geo (Bumi) dan center (pusat). Lihat slamet Hambali, Pengantar Imu Falak, (Yogyakarta: Etose Digital Publishing, 2012), hal. 179.

47 Taufiq, Perkembangan Imu Hisab di Indonesia, hal.17.

48 Izzuddin, Fiqib Hisab Rukyat, hal.52-53.

${ }^{49}$ Izzuddin,Fiqih Hisab Rukyat, hal.53.

${ }^{50}$ Khazin, Ilmu Falak dalam Teori dan Praktik, hal.26.

${ }^{51}$ Khazin, Imu Falak dalam Teori dan Praktik, hal.26. 
Di indonesia, perkembangan hisab rukyat tidak lepas dari adanya jaringan ulama yang melakukan rihlah ilmiah dan menjadikan baramain (Makkah dan Madinah) sebagai pusat studi dan tumpuan rihlah ilmiah. Sehingga tampak pemikiran hisab dan rukyat di Indonesia tidak terlepas dari adanya jaringan ulama ke Timur tengah. Indikator adanya pengaruh pemikiran hisab rukyat di Timur Tengah adalah tampak dari adanya Makkah yang tetap digunakan sebagi pusat beberapa perhitungan hisab rukyat klasik di Indonesia. ${ }^{52}$

Perkembangan selanjutnya, pemikiran-pemikiran hisab rukyat tersebut ternyata sangat mempengaruhi perkembangan hisab rukyat pada zaman berikutnya, di mana banyak yang menjadi re-transplanting terhadap pemikiran hisab rukyat dari Jazirah Arab. Dinamika pencangkokan pemikiran hisab rukyat di Indonesia dari negara-negara lain terjadi pada abad ke-17 hingga abad ke-19. ${ }^{53}$

Adapun ilmuwan-ilmuwan Muslim ahli hisab rukyat bidang astronomi yang berkembang pada masa ini beserta karya ilmiahnya adalah:

a. Ulugh Beik Muhammed Targai Ibn Shah Rakkh Ibn Timur (Ulugh Beik) karyanya adalah Zij Ulugh Beike (Ulugh Beik Astronomical Table), mendirikan observatorium astronomi di Samarkand.

b. Ghaiat ed-Din Massud Ibn Muhammad al-Kashi (al-Kashi) (1436 M) karyanya adalah Kitab Zij al-Khaquani, Rissala an Ibliligiat al Kammar wa Atarid (A Treatise on The Elliptical Moon and Mercury).

c. Taqiyyuddin al-Misri (1575-1580 M) karyanya adalah alat pengukur azimuth.

\section{Hisab dan Rukyat pada Masa Modern (abad ke-19 sampai sekarang).}

Kembali pada temuan Ulugh Beik (1344-1449) yang berupa jadwal Ulugh Beik, pada tahun $1650 \mathrm{M}$ jadwal ini diterjemahkan ke dalam bahasa Inggris oleh J. Greaves dan Thyde, dan oleh Saddilet disalin ke dalam bahasa Prancis. Kemudian Simon New Comb (1835-1909 M) berhasil membuat jadwal astronomi baru ketika beliau berkantor di Nautical al Manac Amerika (1857-1861 M), sehingga jadwalnya sampai sekarang terkenal dengan nama Almanac Nautica. ${ }^{54}$

\footnotetext{
${ }^{52}$ Bashori, Penanggalan Islam, (Jakarta: PT Alex Media Komputindo, 2013), hal.116.

${ }_{53}$ Bashori, Penanggalan Islam, hal.116.

${ }^{54}$ Izzuddin, Fiqib Hisab Rukyat, hal.53-54.
} 
Di Indonesia berkembang ilmu hisab yang berasal dari abad pertengahan, kemudian disusul dengan ilmu hisab yang bersumber dari ilmu astronomi modern dan akhirnya berkembang ilmu hisab yang bersumber dari ilmu astronomi serta ilmu matematika kontemporer. ${ }^{55}$

Masih sangat terlihat di awal abad ke-20 misalnya dengan adanya pemikiran-pemikiran dalam kitab Sullamu nayyirain karya Muhammad Mas Mansur al-Batawi. Bahkan kitab-kitab hisab rukyat yang beredar di awal abad ke-20 merupakan kitab-kitab pengcangkokan dari kitab-kitab ulama-ulama klasik yang juga merupakan pencangkokan dari adanya sebuah pemikiran jaringan ulama. ${ }^{56}$

Masuknya kajian hisab rukyat dan sains ini melengkapi dinamika perkembangan hisab rukyat di Indonesia yang sebenarnya secara aplikatif sudah ada sejak zaman kerajaan Islam di bawah penjajahan Belanda, yaitu penerapan kalender Hijriah sebagai kalender resmi. ${ }^{5}$

Penggunaan kalender Hijriah ini sebenarnya diubah oleh pemerintah Hindia Belanda menjadi kalender Masehi. Namun umat Islam terutama daerah-daerah kerajaan Islam masih menggunakan pedoman kalender Hijriah. bahkan penguasa-penguasa kerajaan memiliki wewenang dalam menetapkan hari-hari yang ada hubungannya dengan persoalan peribadatan seperti penetapan awal bulan kamariah.

Perkembangan hisab rukyat mengalami perkembangan pesat ketika dibawa oleh para ulama, yaitu syekh Taher Jalaluddin al-Azhari, yang disebut sebagai bapak hisab Indonesia, Syeikh Khattib Minang Kabau, KH. Shaleh Darat dan Ahmad Rifa'i. ${ }^{58}$

Selanjutnya perkembangan sistem hisab di Indonesia terjadi pengelompokkan dalam dua kategori, yaitu:

a. Sistem hisab urfi

Hisab urfi merupakan sistem perhitungan penetapan bulanbulan kamariah yang didasarkan pada waktu rata-rata peredaran Bulan. Sistem hisab metode ini dalam prakteknya tidak memperhatikan posisi Bulan, hanya menggunakan perhitungan yang bersifat permanen ${ }^{59}$.

55 Taufiq, Perkembangan Imu Hisab di Indonesia, hal.17.

${ }^{56}$ Bashori, Penanggalan Islam, hal.116.

${ }^{57}$ Bashori, Penanggalan Islam, hal.117.

58 Bashori, Penanggalan Islam, hal.117

${ }^{59}$ Ditbinbapera, dalam Direktorat Jenderal Bimas Islam dan Penyelenggaraan Haji, Selayang Pandang Hisab Rukyat, Jakarta: ttp, 2004), hal.4. 
Sistem hisab ini sudah ditentukan bahwa satu siklus tahun Hijriah ada 30 tahun yakni 11 tahun kabisat berjumlah 355 hari dan 19 tahun basithah berjumlah 354 hari dengan perhitungan satu tahun terdiri dari 12 bulan, 30 hari untuk bulan ganjil dan 29 hari untuk bulan genap kecuali bulan yang ke-12 Zulhijjah yang berjumlah 30 hari pada tahun kabisat. Dan sistem ini berlaku secara berulang-ulang dan terus menerus. ${ }^{60}$

b. Sistem hisab hakiki

Hisab hakiki merupakan sistem perhitungan dalam penentuan awal bulan kamariah dengan metode penentuan kedudukan Bulan pada saat Matahri terbenam. ${ }^{61}$

Metode perhitungan dalam hisab hakiki terbagi lagi menjadi tiga jenis sistem perhitungan, yaitu:

1) Hisab hakiki taqribi

Merupakan sistem perhitungan hisab rukyat yang akurasinya rendah karena basis data yang dijadikan acuanya adalah Zij (tabel astronomi) Ulugh Beik (w. 1449 M) dan dalam pelaksanaan pengamatannya berdasarkan teori geosentrisnya Ptolomeus. ${ }^{62}$ Hisab metode ini menggunakan data Bulan dan Matahari dengan proses perhitungan yang sederhana. Hisab ini dilakukan hanya dengan cara penambahan, pengurangan, perkalian dan pembagian tanpa menggunakan ilmu ukur segitiga bola (spherical trigonometri). ${ }^{63}$

2) Hisab hakiki tahkiki

Merupakan sistem perhitungan hisab rukyat yang memiliki akurasi tinggi namun klasik. ${ }^{64}$ Hisab metode ini dicangkok dari kitab al-Matbla' al-Said Rushd al-Jadid yang berakar dari sistem astronomi serta matematika modern yang asal muasalnya dari sistem hisab astronom-astronom Muslim tempo dulu dan telah dikembangkan oleh astronom-astronom modern Barat berdasarkan penelitian baru. Metode ini adalah menghitung atau menentukan posisi Matahari, Bulan, dan titik simbol orbit Bulan dengan orbit Matahari dalam sistem

${ }^{60}$ Ditbinbapera, Selayang Pandang, hal.4.

${ }^{61}$ Direktorat Jenderal Pembinaan Masyarakat Islam, Almanak Hisab Rukyat, Jakarta: Kementerian Agama RI, 2010), Cet-3, hal.96.

${ }^{62}$ Bashori, Penanggalan Islam, hal.118.

${ }^{63}$ Izzuddin, Fiqib Hisab Rukyat, hal.7.

${ }^{64}$ Bashori, Penanggalan Islam, hal.119. 
koordinat ekliptika, artinya sistem ini mempergunakan tabeltabel yang sudah dikoreksi dan perhitungan yang relatif lebih rumit daripada metode hisab tahkiki taqribi serta sudah memakai ilmu ukur segitiga bola. ${ }^{65}$

3) Hisab hakiki kontemporer

Merupakan sistem perhitungan hisab rukyat yang memiliki akurasi tinggi dengan data-data kontemporer dan biasanya menggunakan berbagai alat bantu seperti kalkulator dan komputer. Metode hisab hakiki kontemporer memiliki tingkat akurasi tinggi karena telah berbasiskan ilmu astronomi. ${ }^{66}$ Metode yang digunakan hampir sama dengan metode yang digunakan dalam hisab hakiki tahkiki hanya saja sistem koreksinya lebih teliti dan mendekati akurat sesuai dengan kemajuan sains dan teknologi. ${ }^{67}$ adalah:

Kitab-kitab yang termasuk hisab hakiki kontemporer ${ }^{68}$

a) New Comb karya Drs. Abdurrahim Yogyakarta

b) EW. Brown karya Drs. Tengku Ali Muda Medan

c) Hisab Awal Bulan karya Saadoeddin Djambek Jakarta

d) Almanak Nautika karya HM. Nautical Inggris NASA

e) Jeun Meuus karya Jeun Meus Belgia

f) Ephemeris Hisab Rukyat karya Departemen Agama RI Jakarta

g) The Astronomical Almanac karya NASA

Dengan demikian sepanjang perjalanan sejarah ilmu hisab dan rukyat menuju era modern mengalami perkembangan yang pesat. Hal ini bisa dijumpai dari metode-metode yang digunakan dengan tingkat koreksi yang semakin akurat. Selain itu, banyak tulisan dan instrumen juga yang diciptakan pada masa ini. Semakin pesatnya ilmu hisab rukyat menunjukkan semakin pesatnya juga perkembangan peradaban Islam.

\footnotetext{
${ }^{65}$ Izzuddin, Fiqih Hisab Rukyat, hal.7.

${ }^{66}$ Bashori, Penanggalan Islam, hal.120.

${ }^{67}$ Izzuddin, Fiqib Hisab Rukyat, hal.8.

${ }^{68}$ Bashori, Penanggalan Islam, hal.120.
} 


\section{Penutup}

Berdasarkan pembahasan di atas dapat disimpulkan bahwa pengertian mengenai hisab dan rukyat mengalami penyempitan makna, dari ilmu perhitungan dan astronomi (bumi dan antariksa) menjadi ilmu falak yang khusus untuk beribadatan umat Islam. Dalam sejarah peradaban Islam, hisab rukyat telah mengalami perkembangan yang pesat. Hal ini dapat dilihat dari lahirnya sejumlah ilmuwan yang hebat,terciptanya penemuan-penemuanbaru baik dalam bentuk teori maupun instrumen-instrumen (klasik hingga modern) serta banyaknya observatorium yang didirikan wilayah Islam.

Perkembangan hisab rukyat memiliki korelasi yang sangat penting dalam pesatnya peradaban Islam seiring perjalanan sejarahnya. Misalnya di Indonesia pemikiran hisab rukyat dari Timur Tengah terjadi re-transplanting yang digunakan dalam kajian kitab-kitab hisab rukyat klasik. Begitu juga di dunia Barat pemikiran hisab rukyat karya ulama-ulama terdahulu diterjemahkan dan digunakan sebagai rujukan, seperti Zij Ulugh Beik yang sekarang berkembang menjadi astronomi modern dengan perhitungan ketelitian yang lebih akurat bahkan digunakan juga umat Islam dalam perhitungan Ilmu Falak. 


\section{Daftar Pustaka}

Azhari, Susiknan, Kalender Islam ke Arah Integrasi Mubammadiyah-NU, Yogyakarta: Museum Astronomi Islam, , 2012.

Bashori, Muh. Hadi, Penanggalan Islam, Jakarta: PT Alex Media Komputindo, 2013.

Bukhari, al-, Shahih Bukhari, Mesir: Musthafa al-Babi al-Halabi, juz III,tth.

Direktorat Jenderal Bimas Islam dan Penyelenggaraan Haji, Selayang Pandang Hisab Rukyat, Jakarta: ttp, 2004.

Direktorat Jenderal Pembinaan Masyarakat Islam, Almanak Hisab Rukyat, Jakarta: Kementerian Agama RI, Cet-3, 2010.

Ramdan, Anton, Islam dan Astronomi, Jakarta: Bee Media Indonesia, 2009.

Hajjaj, Abu Husain Muslim bin al, Shabih Muslim, Jilid 2, Beirut: Dar al-Fikr, tt.

Hambali, Slamet, Pengantar Imu Falak, Yogyakarta: Bismillah Publisher, 2012.

Izzuddin, Ahmad, Fiqih Hisab Rukyat, Jakarta: Penerbit Erlangga, 2007.

Jannah, Sofyan, Kalender Hijriah dan Masehi 150 Tabun, Yogyakarta: UII Press, 1994.

Khazin, Muhyiddin, Ilmu Falak dalam Teori dan Praktik, Yogyakarta: Buana Pustaka, 2008.

King, David A, Astronomi in The Servic of Islam, Great Britain: Voriorium Ashgate Publishing, 1993.

Munawwir, Ahmad Warson, Al Munawnir Kamus Arab-Indonesia, Surabaya: Penerbit Pustaka Progressif, cet-14, 1997.

Pannekoek, A., A. History of Astronomy, New York: Dover Publications Inc, 1961.

Saksono, Tono, Mengkompromikan Hisab dan Rukyat, Jakarta: PT. Amythas Publicita, 2007.

https://tikotea.wordpress.com/2009/09/16/sumbangan-saintis-muslimdalam-geometri/

http://archive.aramcoworld.com/issue/200703/rediscovering.arabic.science. htm

http://www.themodernreligion.com/basic/history/photographs_science.ht $\mathrm{m}$ 
Li’izza Diana Manzil: Korelasi Historisitas Ilmu Hisab Rukyat Dengan Perkembangan | 206 